\title{
KAJIAN AKTIVITAS ANTIBAKTERI EKSTRAK ETANOL DAUN JATI BELANDA (Guazuma ulmifolia Lamk) TERHADAP PERTUMBUHAN Streptococcus mutans
}

\author{
Sri Wahyuni ${ }^{1^{*}}$, Rissa Laila Vifta ${ }^{2}$, Agitya Resti Erwiyani ${ }^{3}$ \\ Program Studi Farmasi, Fakultas Ilmu Kesehatan, Universitas Ngudi Waluyo \\ Jalan Gedongsongo, Candirejo, Ungaran Barat \\ *Email korespondensi : sriwahyuni@gmail.com
}

\begin{abstract}
Abstrak
Daun Jati Belanda (Guazuma ulmifolia Lamk) mengandung flavonoid, saponin dan tanin yang dapat menghambat pertumbuhan bakteri Streptococcus muatans. Penelitian ini dilakukan dengan tujuan mengetahui pengaruh ekstrak etanol daun jati belanda (Guazuma ulmifolia Lamk) sebagai kandidat antibakteri terhadap Streptococcus mutans. Jenis penelitian yang digunakan adalah eksperimental murni dengan desain post tes control group design menggunakan metode difusi sumuran pada 5 kelompok perlakuan. Kontrol positif mengandung Ciprofloxacin, kontrol negatif mengandung aquadest, kontrol media dan kontrol pertumbuhan, perlakuan 1 ekstrak $30 \% \mathrm{~b} / \mathrm{v}$, perlakuan 2 ekstrak $40 \% \mathrm{~b} / \mathrm{v}$, Perlakuan 3 ekstrak $50 \%$ b/v. Data hasil di evaluasi menggunakan SPSS 24.0 For Windows dengan taraf kepercayaan 95\%. Ekstrak etanol daun jati belanda (Guazuma ulmifolia Lamk) menghasilkan zona hambat bakteri Streptococcus mutans dengan konsentrasi $30 \%$ sebesar $1,03 \mathrm{~cm}$, konsentrasi $40 \%$ sebesar 1,45 cm, 50\% sebesar 1,81 cm, kontrol positif sebesar 1,77 cm, dan kontrol negatif sebesar 0,00 cm. Ekstrak etanol daun jati belanda (Guazuma ulmifolia Lamk) mempunyai aktivitas menghambat bakteri Streptococcus mutans. Pada konsentrasi 50\% ekstrak etanol daun jati belanda (Guazuma ulmifolia Lamk) dapat menghambat bakteri Streptococcus mutans yang sebanding dengan ciproploxacin.
\end{abstract}

Kata Kunci: Antibakteri, daun Jati Belanda, Streptococcus mutans.

\section{PENDAHULUAN}

Karies gigi merupakan penyakit pada jaringan keras gigi akibat aktifitas dari bakteri penghasil asam yang mampu melakukan fermentasi karbohidrat yang di konsumsi pada manusia. Salah satu bakteri yang dianggap sebagai agen utama penyebab karies gigi adalah Streptococcus mutans. Komponen plak gigi dari mikroorganisme normal rongga mulut ini dapat menjadi patogen jika populasinya meningkat sehingga proses karies berlangsung meningkat lebih cepat (Natarini et al., 2007).

Antibakteri merupakan zat yang dapat mengganggu pertumbuhan atau bahkan mematikan bakteri dengan cara mengganggu metabolisme mikroba yang merugikan. Salah satu antibakteri yang banyak digunakan adalah antibiotik. Antibiotik adalah senyawa kimia khas yang dihasilkan atau diturunkan oleh organisme hidup termasuk struktur analognya yang dibuat secara sintetik, yang dalam kadar rendah mampu menghambat proses penting dalam kehidupan satu spesies atau lebih mikroorganisme. Antibiotik merupakan obat yang paling banyak digunakan pada infeksi yang disebabkan oleh bakteri (Siswandono dan Soekardjo, 1995). Pemakaian antibiotik memiliki banyak efek samping seperti alergi dan gangguan pencernaan, sehingga penggunaan obat-obatan berbahan baku herbal lebih disarankan. Peningkatan resistensi bakteri terhadap antibiotik memberikan peluang besar untuk mendapatkan senyawa antibakteri dengan memanfaatkan senyawa bioaktif dari kekayaan keanekaragaman hayati (Windy, 2013).

Daun Jati Belanda (Guazuma ulmifolia Lamk.) merupakan salah satu tanaman yang belum dimanfaatkan secara maksimal. Bagian yang banyak digunakan sebagai bahan obat adalah bagian daun, kulit batang, dan biji. Daun berkhasiat sebagai pelangsing tubuh, dan bijinya sebagai obat mencret, sembelit, karminatif dan bagian dalam kulit batang tanaman Jati Belanda dipakai untuk mengobati penyakit cacing dan kaki gajah, dan bagian buah untuk obat diare, batuk, nyeri perut, sementara kulitnya dipakai untuk menciutkan urat darah. 
Penelitian yang dilakukan oleh Tumbel (2009) yang berjudul uji daya hambat ekstrak metanol daun Jati Belanda (Guazuma ulmifolia Lamk) terhadap pertumbuhan bakteri Eschericia coli dengan konsentrasi $5 \%$ b/v, $10 \% \mathrm{~b} / \mathrm{v}, 20 \% \mathrm{~b} / \mathrm{v}$ dan larutan Na CMC $1 \%$ sebagai kontrol. Hasil menunjukkan bahwa ekstrak metanol daun Jati Belanda memiliki daya hambat yang signifikan terhadap pertumbuhan E.coli dengan konsentrasi $20 \%$ adalah 12,67 mm, untuk konsentrasi 10\% adalah $11 \mathrm{~mm}$, sedangkan konsentrasi $5 \%$ adalah 9,67 $\mathrm{mm}$.

Berdasarkan uraian tersebut, maka peneliti tertarik untuk meneliti kajian lebih lanjut untuk menguji aktivitas antibakteri ekstrak etanol daun Jati Belanda (Guazuma ulmifolia Lamk) terhadap pertumbuhan bakteri Streptococcus mutans.

\section{METODE PENELITIAN}

\section{Alat dan Bahan}

Alat

Seperangkat alat maserasi, blender, neraca, batang pengaduk, kertas saring, erlemeyer, gelas ukur, penangas air, ayakan no.30 mesh, Laminar air flow, cawan petri, jangka sorong, mikro pipet, tabung reaksi, oven, autoklaf, inkubator, lampu spiritus, jarum ose, dan waterbath.

\section{Bahan}

Bahan yang digunakan adalah daun Jati Belanda (Guazuma ulmifolia Lamk), Suspensi bakteri Streptococcus mutans, aquadest, etanol $70 \%$, ciprofloxacin, dan media MHA.

\section{Prosedur Penelitian \\ Jenis dan Rancangan Penelitian}

Penelitian ini adalah penelitian eksperimen murni (True Eksperimental) dengan desain penelitian Pottest Only Control Group Design. Penelitian ini dengan melihat zona hambat ekstrak etanol daun Jati Belanda pada masing-masing konsentrasi $30 \% \mathrm{~b} / \mathrm{v}, 40 \% \mathrm{~b} / \mathrm{v}$, dan $50 \% \mathrm{~b} / \mathrm{v}$.

\section{Pembuatan Ekstrak Etanol daun Jati Belanda (Guazuma ulmifolia Lamk) Penyiapan Bahan}

Daun Jati Belanda (Guazuma ulmifolia Lamk) yang masih segar diperoleh dari daerah Bawen. Daun Jati Belanda yang telah dikumpulkan lalu dibersihkan dan dicuci dengan air mengalir dilakukan sortasi basah, kemudian dilakukan perajangan pada daun Jati Belanda dan dikeringkan di bawah sinar matahari langsung ditutupi dengan kain hitam. Hal ini bertujuan untuk menghindari kerusakan senyawa kimia yang terkandung dalam daun Jati Belanda. Sampel yang telah kering kemudian dibuat serbuk dengan menggunakan blender, kemudian serbuk yang dihasilkan diayak menggunakan ayakan No.30 mesh, sehingga diperoleh serbuk yang halus dan hasil serbuk disimpan dalam wadah bersih tertutup rapat.

\section{Ekstraksi Daun Jati Belanda (Guazuma ulmifolia Lamk)}

Pembuatan ekstrak daun Jati Belanda (Guazuma ulmifolia Lamk) yaitu menggunakan metode maserasi. Ditimbang sebanyak 1200 gram serbuk halus, dimasukkan dalam panci, kemudian dimasukkan pelarut etanol $70 \%$ sebanyak $8550 \mathrm{ml}$ dan dibiarkan selama 5 hari sambil seringkali diaduk, didiamkan selama 5 hari. Setelah 5 hari sampel yang direndam tersebut disaring menggunakan kertas saring menghasilkan maserat pertama dan ampas pertama. Ampas pertama yang di dapatkan kemudian ditambah dengan larutan etanol sebanyak $3500 \mathrm{ml}$, dan dibiarkan selama 2 hari sambil sesekali diaduk, setelah 2 hari, sampel tersebut disaring dengan kertas saring dihasilkan maserat kedua dan ampas kedua. Kemudian maserat pertama dan maerat kedua dicampur menjadi satu, kemudian diuapkan menggunakan waterbath pada suhu $60^{\circ} \mathrm{C}$, sehingga diperoleh ekstrak kental daun Jati Belanda

\section{Penapisan Fitokimia}

Penapisan fitokimia dilakukan untuk mengidentifikasi senyawa flavonoid, alkaloid, tanin, dan saponin yang terkandung dalam daun Jati Belanda (Guazuma ulmifolia Lamk)

\section{1) Identifikasi Flavonoid}

Ekstrak ditambah metanol dan kocok selama 15 menit dengan menutup rapat mulut tabung, saring, filtrat diteteskan pada kertas saring dan diuapkan dengan amoniak pekat. Warna kuningan atau bercak kuning pada kertas saring menunjukkan adanya kandungan flavonoid.

\section{2) Identifikasi Saponin}

Ekstrak dimasukkan dalam tabung reaksi ditambah aquadest, didihkan selama 2-3 menit, dinginkan, setelah dingin dikocok 
dengan kuat. Uji positif ditandai dengan adanya busa yang stabil selama 5 menit.

\section{3) Identifikasi Tanin}

Dua gram ekstrak ditambahkan aquadest kemudian didihkan selama beberpa menit. Selanjutnya dilakukan penyaringan dan filtrat yang diperoleh ditambahkan 3 tetes $\mathrm{FeCl}_{3}$ warna biru tua atau hitam kehijauan yang terbentuk menunjukkan adanya senyawa tanin

\section{4) Identifikasi Alkaloid}

Uji alkaloid dilakukan dengan menggunakan pereaksi Mayer dan dikocok. Alkaloid dianggap positif jika timbul endapan berwarna putih

\section{Pembuatan Media MHA}

MHA ditimbang sebanyak 3,4 g, dilarutkan dalam $100 \mathrm{ml}$ aquadest, dipanaskan hingga mendidih di atas hotplate. Media dimasukkan ke dalam tabung, disterilkan dengan autoklave selama 15 menit pada suhu $121^{\circ} \mathrm{C}$ dan disimpan dalam lemari es jika akan dipergunakan, dipanaskan hingga mencair kembali. Media MHA dalam tabung dituang dalam cawan petri.

\section{Inokulasi Bakteri Pada Media Agar}

Bakteri uji (Streptococcus mutans) diambil dengan jarum ose steril, lalu ditanamkan pada media agar dengan cara menggoreskan. Selanjutnya diinkubasi dalam inkubator pada suhu $37^{\circ} \mathrm{C}$ selama 24 jam.

\section{Pembuatan Suspensi Bakteri}

Bakteri Streptococcus mutans yang telah diinokulasi diambil dengan kawat ose steril lalu disuspensikan dengan menggunakan $\mathrm{NaCl} 0,9 \%$ dan diinkubasi selama 24 jam pada suhu $37^{\circ} \mathrm{C}$.

\section{Pengujian Antibakteri Ekstrak daun Jati} Belanda (Guazuma ulmifolia Lamk)

Metode yang digunakan untuk uji antibakteri menggunakan sumuran dengan memodifikasi prosedur Nurfajrina dkk, (2016). Sebanyak $10 \mathrm{ml}$ media MHA (sebagai lapisan dasar), diletakkan 5 Cylender cup diatas lapisan dasar yang telah memadat. Suspensi bakteri uji Streptococcus mutans sebanyak $100 \mu \mathrm{l}$ dimasukkan ke dalam $10 \mathrm{ml}$ media MHA, kemudian dituang secara aseptis ke dalam cawan petri steril yang telah diisi lapisan dasar yang telah diletakkan Cylinder cup untuk membentuk sumuran dan dibiarkan memadat.
Selanjutnya dilakukan pengisian dengan larutan ekstrak etanol daun Jati Belanda pada masingmasing variasi konsentrasi $30 \%$ pada lubang pertama, $40 \%$ pada lubang kedua, $50 \%$ pada lubang ketiga, kontrol positif (Ciprofloxacin) pada lubang keempat, dan kontrol negatif (aquadest steril) pada lubang kelima. Setelah semua terisi larutan cawan petri kemudian diinkubasi pada suhu $37^{\circ} \mathrm{C}$ selama 24 jam. Cawan petri dikeluarkan dan Cylinder cup diambil menggunakan pinset. Diamati dan diukur terbentuknya zona hambatan yang terjadi disekitar Cylinder cup, diukur menggunakan jangka sorong, dilakukan replikasi sebanyak 3 .

\section{Analisis Data}

Analisis data penelitian secara statistik dengan menggunakan SPSS (Statistical Product and Service Solutions) versi 16 didahului dengan uji normalitas menggunakan rumus dari Shapiro-Wilk dan uji homogenitas menggunakan rumus dari Lavene Test. Kemudian, data dianalisis dengan statistik parametik ANAVA satu jalan dan dilanjutkan dengan uji LSD.

\section{HASIL DAN PEMBAHASAN \\ Determinasi Tanaman}

Tahap awal sebelum dilakukan penelitian ini adalah dilakukan determinasi terhadap daun Jati Belanda (Guazuma ulmifolia Lamk.). Determinasi tanaman bertujuan untuk mengetahui kebenaran tanaman dan menghindari kesalahan dalam pengumpulan bahan terutama mencegah kemungkinan tercampurnya tanaman yang diteliti dengan tanaman yang lain. Berdasarkan hasil determinasi dapat dipastikan bahwa bahwa tanaman yang digunakan benar tanaman daun Jati Belanda (Guazuma ulmifolia Lamk). Hasil determinasi tanaman daun Jati Belanda dinyatakan sebagai berikut.

Kingdom : Plantae

Sub Kingdom : Tracheobionta

Super Devisi : Spermatophyta

Divisi : Magnoliophyta

Kelas : : Magnoliopsida

Ordo : :Malvales

Famili : Sterculiaceae

Genus : Guazuma

Spesies : : Guazuma ulmifolia Lamk. 


\section{Ekstraksi daun Jati Belanda (Guazuma ulmifolia Lamk)}

Pembuatan ekstraksi daun Jati Belanda (Guazuma ulmifolia Lamk) dilakukan dengan metode maserasi hingga diperoleh hasil ekstrak kental. Hasil maserasi dicantumkan pada Tabel 1.

Tabel 1. Hasil rendemen ekstrak etanol Daun Jati Belanda

\begin{tabular}{|c|c|c|c|c|}
\hline \multirow{2}{*}{$\begin{array}{l}\text { Bobot } \\
\text { serbuk } \\
\text { (gram) }\end{array}$} & \multirow{2}{*}{$\begin{array}{l}\text { Bobot } \\
\text { ekstrak } \\
\text { (gram) }\end{array}$} & \multirow{2}{*}{$\begin{array}{l}\text { Rende } \\
\text { men } \\
(\%)\end{array}$} & \multicolumn{2}{|c|}{ Karakteristik } \\
\hline & & & Bentuk & Warna \\
\hline $1200 \mathrm{~g}$ & $130 \mathrm{~g}$ & $10,8 \%$ & Kental & $\begin{array}{l}\text { Hijau } \\
\text { kehitaman }\end{array}$ \\
\hline
\end{tabular}

Metode maserasi dipilih karena merupakan metode pemisahan yang sederhana dan penguapanya menggunakan waterbath dengan suhu $60^{\circ} \mathrm{C}$ sehingga kandungan senyawa metabolit sekunder seperti flavonoid, saponin, dan tanin yang ada pada daun Jati Belanda (Guazuma ulmifolia Lamk) tidak rusak atau terurai karena flavonoid tidak mengalami kerusakan sampai pada suhu $90^{\circ} \mathrm{C}$, saponin tahan pada suhu $70^{\circ} \mathrm{C}$, dan tanin akan terurai pada suhu $98,89^{\circ} \mathrm{C}-101,67^{\circ} \mathrm{C}$. Serbuk daun Jati Belanda sebanyak 1200 gram menghasilkan ekstrak kental sebanyak 130 gram dengan presentase $10,6 \%$. Persentase rendemen menunjukkan kemaksimalan dari pelarut yang digunakan untuk menyari. Pelarut yang digunakan etanol $70 \%$ karena bersifat polar. Hasil ekstrak etanol daun Jati Belanda (Guazuma ulmifolia Lamk) yang diperoleh berbentuk kental, berwarna hijau kehitaman dan berbau khas.

\section{Penapisan Fitokimia}

Penapisan fitokimia dilakukan secara kualitatif melalui uji tabung dengan tujuan mengetahui skrining awal senyawa aktif yang terkandung dalam ekstrak etanol daun Jati Belanda (Guazuma ulmifolia Lamk). Hasil penapisan fitokimia ditunjukkan pada Tabel 2.

Tabel 2. Hasil Penapisan Fitokimia daun Jati Belanda (Guazuma ulmifolia Lamk)

\begin{tabular}{lll}
\hline Uji fitokimia & Hasil organoleptis & Ket \\
\hline Flavonoid & $\begin{array}{l}\text { Terbentuk warna } \\
\text { kuning }\end{array}$ & $(+)$ \\
\hline Tanin & $\begin{array}{l}\text { Terbentuk hijau } \\
\text { kehitaman }\end{array}$ & $(+)$ \\
\hline Saponin & $\begin{array}{l}\text { Adanya terbentuk } \\
\text { busa stabil }\end{array}$ & $(+)$ \\
\hline Alkaloid & Tidak ada endapan & $(-)$ \\
\hline
\end{tabular}

Berdasarkan data pada Tabel 2, hasil penapisan uji fitokimia menunjukkan bahwa ekstrak daun Jati Belanda mengandung senyawa flavonoid, saponin, dan tanin.

Hasil uji flavonoid dengan perubahan dari warna kuning menjadi warna merah setelah ditambahkan larutan $\mathrm{H}_{2} \mathrm{SO}_{4}$. Hal ini dikarenakan senyawa flavonoid dalam tanaman membentuk glikosida dan aglikon (aglikon polimetoksi dan aglikon polihidroksi) (Rohyami dan Yulia, 2008).

Hasil uji saponin ditandai dengan terbentuknya busa yang stabil setelah ditambahkan aquadest dua tetes kemudian dididihkan selama 2-3 menit, membuktikan adanya saponin. Timbulnya busa pada uji saponin menunjukkan adanya glikosida yang mempunyai kemampuan membentuk buih dalam air yang terhidrolisis menjadi glukosa dan senyawa lainnya.

Hasil uji tanin ditandai dengan adanya warna hijau kehitaman. Hasil uji menunjukkan positif dengan terbentuknya warna hijau. Hal ini disebabkan karena senyawa tanin membentuk senyawa yang kompleks dengan ion Fe (Marliana et al, 2005).

\section{Hasil Uji Antibakteri Staphylococcus mutans}

Hasil uji aktivitas antibakteri ekstrak daun Jati Belanda (Guazuma ulmifolia Lamk) dapat dilihat pada Tabel 3.

Tabel 3. Zona hambat bakteri Streptococcus mutans

\begin{tabular}{lll}
\hline $\begin{array}{l}\text { Kelompok } \\
\text { Perlakuan }\end{array}$ & $\begin{array}{l}\text { Mean } \\
(\mathrm{cm})\end{array}$ & SD \\
\hline Kontrol negatif & 0,00 & 0,00 \\
Kontrol positif & 1,77 & 0,02 \\
Konsentrasi 30\% & 1,03 & 0,07 \\
Konsentrasi 40\% & 1,45 & 0,03 \\
Konsentrasi 50\% & 1,81 & 0,05 \\
\hline
\end{tabular}

Berdasarkan data pada Tabel 3 menunjukkan bahwa hasil zona hambat ekstrak daun Jati Belanda pada Streptococcus mutans menghasilkan diameter zona hambat dengan hasil rata-rata sebesar $1,03 \pm 0,07 \mathrm{~cm}$ untuk konsentrasi $30 \%, 1,45 \pm 0,03 \mathrm{~cm}$ konsentrasi

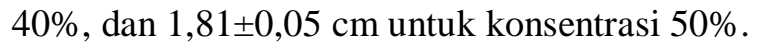
Hasil tersebut menunjukkan bahwa ekstrak etanol daun Jati Belanda memiliki aktifitas daya hambat terhadap Streptococcus mutans.

Daun Jati Belanda mengandung flavonoid, saponin, dan tanin. Flavonoid bersifat antibakteri karena mempunyai 
kemampuan untuk merusak protein ekstraseluler dan protein yang larut serta merusak dinding sel bakteri. Mekanisme saponin sebagai antibakteri dengan mengganggu permeabilitas membran sel bakteri, yang mengakibatkan kerusakan membran sel dan menyebabkan keluarnya berbagai komponen penting dari dalam sel bakteri yaitu protein, asam nukleat dan nukleotida (Ganiswara, 1995). Sedangkan tanin sebagai antibakteri adalah menghambat enzim reverse transtiptase dan DNA topoisomerase sehingga sel bakteri tidak dapat terbentuk (Robinson, 1995).

\section{Analisis Statistik}

Data diameter zona hambat ekstrak etanol daun Jati Belanda dianalisis menggunakan Shapiro Will dengan nilai pvalue lebih dari 0.05 y`ang menunjukkan data terdistribusi normal, selanjutnya di uji Anava satu jalan dengan p-value kurang dari 0.05 dengan nilai F-hitung lebih besar daripada Ftabel, sehingga data dapat dianalisis lebih lanjut.

Tabel 4. Hasil uji statistika dengan Anava

\begin{tabular}{lll}
\hline Bakteri & F Hitung & F tabel \\
\hline Streptococcus mutans & 1052.86 & 3,48 \\
\hline
\end{tabular}

Uji lanjut dilakukan menggunakan uji LSD dengan tujuan mengetahui perbandingan masing-masing kelompok perlakuan. Hasil uji LSD masing-masing kelompok disampaikan pada Tabel 5 .

Tabel 5. Hasil Uji LSD dengan metode Pos Hoc

\begin{tabular}{lll}
\hline Kelompok perlakuan & Sig. & Ket \\
\hline KP vs K30\% & 0.000 & beda signifikan \\
KP vs K40 \% & 0.000 & $\begin{array}{l}\text { beda signifikan } \\
\text { tidak beda } \\
\text { signifikan }\end{array}$ \\
\hline
\end{tabular}

Keterangan :

KP : Kontrol positif (ciprofloxacin)

K30\% : Konsentrasi 30\%

K40\% : Konsentrasi 40\%

K50\% : Konsentrasi 50\%

Hasil uji LSD menunjukkan konsentrasi $50 \%$ memiliki aktifitas yang sebanding atau tidak berbeda signifikan dengan kontrol positif. Hal ini menunjukkan bahwa pada konsentrasi tersebut aktifitas antimikroba ekstrak etanol daun Jati Belanda bekerja dengan baik.
Aktifitas penghambatan bakteri dipengaruhi senyawa aktif yang terkandung di dalam ekstrak. Semakin tinggi konsentrasi ekstrak, maka semakin besar pula diameter zona hambat yang terbentuk disekeliling sumuran. Selain faktor konsentrasi, jenis bahan antimikroba juga menentukan kemampuan menghambat pertumbuhan kuman (Ajizah, 2004). Dalam penelitian ini, aktivitas antibakteri ekstrak etanol daun Jati Belanda (Guazuma ulmifolia Lamk) terbukti mempunyai kandungan senyawa aktif flavonoid, saponin, dan tanin dimana ketiga senyawa tersebut mempunyai efek bakteriostatik.

\section{KESIMPULAN}

Hasil pengujian antibakteri terhadap daun Jati Belanda (Guazuma ulmifolia Lamk) menunjukkan bahwa ekstrak etanol daun Jati Belanda (Guazuma ulmifolia Lamk) memiliki aktifitas bakteriostatik terhadap Streptococcus mutans. Konsentrasi $50 \%$ ekstrak etanol daun Jati Belanda (Guazuma ulmifolia Lamk) dapat menghambat bakteri Streptococcus mutans yang sebanding dengan Ciproploxacin.

\section{DAFTAR PUSTAKA}

Ajizah, A., 2004. Sensitivitas Salmonella Typhimurium terhadap Ekstrak Daun Psidium Guajava L. Bioscientiae. Vol. 1 No.1 : pp: 8-31.

Marliana, Suryanti, dan Suyono, 2005, Skrining Fitokimia dan Analisis Kromatografi Lapis Tipis Komponen Kimia Buah Labu Siam (Sechium edule Jacq. Swartz.) dalam Ekstrak Etanol, Biofarmasi 3 (1): 26-31.

Natarini, Febrina, Whidia. 2007. Perbandingan Efek Antii Bakteri Jus Anggur Merah (Vitisvinifera) Pada Berbagai Konsentrasi Terhadap Streptococcus mutans. Karya Tulis Ilmiah. Universitas Diponegoro Semarang. Semarang.

Nurfajrina H, Sulistyarani I, Wulandari. 2016. Uji Aktivitas Ekstrak Etanol, Fraksi nHeksan, Fraksi Etil Asetat dan Fraksi Daun Alpukat (Parsea america Mill) Terhadap Bakteri Streptococcus mutans. Skripsi. Sekolah tinggi Ilmu Farmasi Yayasan Farmasi Semarang.

Robinson, T., 1995, Kandungan Organik Tumbuhan Tingkat Tinggi, diterjemahkan 
oleh Kosasih Padmawinata, Penerbit ITB, Bandung.

Rohyami dan Yulia., 2008. Penentuan Kandungan Flavonoid Dari Ekstrak Metanol Daging Buah Mahkota Dewa (Phaleria macrocarpa Scheff Boerl). FMIPA UII. Jurnal Vol. 5 No.1. Yogyakarta.

Siswandono dan Soekardjo., 2003. Kimia Medisinal. Penerbit Airlangga University Press. Halaman 544. Surabaya.

Tumbel. M. 2009. Uji Daya Hambat Ekstrak Metanol Daun Jati Belanda Terhadap Pertumbuhan Eshcericia coli. Jurnal Chemica, Vol. 10, No. 2, 85-91

Windy, T. R. 2013. Uji Aktivitas Antibakteri Fraksi Ekstrak Etanol Batang Inggu (Ruta angustifolia (L.) Pers) Terhadap Mencit Yang Diinfeksi Streptococcus mutans dan Staphylococcus aureus. Skripsi. Surakarta. Fakultas Farmasi Universitas Muhammadiyah Surakarta. 